\title{
The Mediator Role of Business Dynamism in the Impact of Innovation Ability of Countries on Entrepreneurial Intentions ${ }^{*}$
}

\author{
Özdemir Yavaş \\ Lecturer \\ Uzunkopru Vocational College \\ Trakya University \\ Tülay Demiralay \\ Associate Professor \\ Kesan Yusuf Capraz School of Applied Sciences \\ Trakya University \\ İlkay Demiralay \\ Lecturer \\ Tunca Vocational College \\ Trakya University
}

\begin{abstract}
The main purpose of this research is to determine the mediator role of business dynamism in the impact of innovation ability of countries on entrepreneurial intentions. The data of innovation ability and business dynamism of 45 countries obtained from the World Economic Forum's Global Competitiveness Index for 2018 and their data of entrepreneurial intention obtained from the Global Entrepreneurship Monitor were included in the research. The conceptual model was evaluated with PROCESS, a multifaceted modeling tool developed by Andrew F. Hayes, which integrates many functions for SPSS and SAS for different statistical analyses such as mediator, regulatory and conditional process models, by mediation analysis. According to the findings of the analysis, it is understood that the innovation ability of the countries have a direct impact on the entrepreneurial intention, but business dynamism plays a complete mediator role in this impact and a significant part of the total impact is indirectly occurred with business dynamism.
\end{abstract}

Keywords: Innovation Ability, Business Dynamism, Entrepreneurial Intentions, PROCESS

\section{Introduction}

The competitive focus of companies and countries has emerged as innovation as a result of similar consumption preferences of people living in countries with different economic and cultural characteristics around the world with the impact of the rapid developments in information and communication technologies, and reducing barriers to labor, capital and products circulation with bilateral and multilateral agreements between countries.

While the innovations that companies create in their different functions during their activities provide a competitive advantage in meeting the demands of consumers, they bring benefits (employment, tax, information production) from these economic activities to the countries where the centers of these countries are located. However, country governments should implement policies to reveal innovation ability so that the innovative companies can maintain their benefits to their countries.

Entrepreneurs' intentions to establish a business model may be influence by policies to promote innovation ability implemented by country governments. This is because policies that promote innovation ability and affect entrepreneurial intentions with being implemented by country governments may create important opportunities for entrepreneurs. Entrepreneurs can set up a business model by determining the fields of entrepreneurship one can take up through the country policies and analyzing other business dynamics in the country.

The main purpose of this research is to determine the mediator role of business dynamism in the impact of innovation ability of countries on entrepreneurial intentions. Thus, the study includes literature review in the second section,

\footnotetext{
*The first version of this study, as full text, was included in the Proceedings Book of the 4th International Entrepreneurship, Employment
} and Career Congress held in Bodrum/Turkey on October 17-20, 2019. 
information about the concepts in the research in the third section, and the method, analysis and findings of the research in the fourth section. The fifth section of the research is also the conclusion section.

\section{Literature Review}

Golden and Lee (2003) could not identify a relationship between national innovation systems and entrepreneurial activities in their studies using the national data of the Netherlands, Ireland and Finland to examine the possible relationship between the concept of National Innovation Systems (NIS) and entrepreneurial efforts.

Zhao (2005) identified a positive correlation between entrepreneurship and innovativeness according to the qualitative research result (a three-stage qualitative study and literature review, semi-structured interviews with 6 senior executives and 6 case studies) conducted to determine the relationship between entrepreneurship and innovativeness in Australia. The combination of two factors is vital for corporate success and sustainability in today's dynamic and changing environment.

Nystrom (2010) found that there was a positive relationship between entrepreneurship and the quality of business arrangements in his study conducted with the data of 23 OECD countries between 1972 and 2002 in order to determine the relationship between labor market regulations and entrepreneurial activities in the countries.

Jackson et al. (2014) conducted a study using the data of 121 countries for 2008 to identify the factors determining the innovative ability of a country and they found that these factors are business world (business networks and supportive sectors), labor market productivity and quality of public institutions.

Yurtkoru et al.'s (2014) research on 425 college students to investigate the impact of the contextual factors on entrepreneurial intentions of college students stated that Turkish economy offered many opportunities to entrepreneurs and entrepreneurs in Turkey were encouraged by a structural system containing private, public and non-governmental organizations. The findings of the research also show that encouraging and educational programs have been recently developed to increase entrepreneurship in the society, but these programs usually result in small businesses that do not have an innovative aspect.

Ozarali and Rivenburgh's (2016) comparative research on 589 students at universities in the United States and Turkey to examine the priorities of entrepreneurship on the basis of social, communal and personality characteristics found that both U.S. and Turkish students had low entrepreneurial intentions, although they exhibited a positive attitude towards entrepreneurship. In addition, both U.S. and Turkish students were determined to need more education and training in entrepreneurship to start a new job. While U.S. students perceived a high risk of entrepreneurship, Turkish students stated that the inconvenience of economic and political conditions in their own countries, including business dynamism being the subject of this research, is the biggest obstacle to setting up their own businesses.

Belas et al. (2017) performed a study on 409 students from 14 universities in the Czech Republic and 568 students from 8 universities in Slovakia in order to examine the dependency of entrepreneurship tendency on social and economic factors among higher education students. As a result of the study, having an entrepreneur in the family, preparing high quality conditions for the business world, improving the business environment in the country in the last five years, the convenience of credit terms of commercial banks, the quality of the education system of universities, having the ability to do business, the presence of an irregular income as the most important disadvantage of doing business and lastly one's interest in work were found to be the most important factors that positively affect students' entrepreneurship tendency.

Mirjana et al. (2018) conducted a research on 330 undergraduate and postgraduate students in Slovenia to determine the factors affecting entrepreneurial intention within the framework of the theory of planned behavior and personal innovative cognitive style, and they found that personal attitudes, subjective norms, perceived behavioral control and innovative personal style correlated positively with the entrepreneurial intention.

Ji and Bai (2018) identified in their research on 1263 students, including 988 undergraduate students and 275 graduate students, to determine the relationship between innovative capacity and entrepreneurial intention, and they found that the perceived entrepreneurial atmosphere significantly affected the entrepreneurial intention and the perceived entrepreneurial desires and feasibility considerably mediated this relationship.

Babina and Howell's (2018) study on 10,541 employees to determine how R\&D affects employee entrepreneurship by using the U.S. census matched employer-employees panel data in the U.S.concluded that the national tax deductions provided to $R \& D$ were effective in directing employees to entrepreneurship. 
When the literature on the subject of the research was examined, a positive correlation was found between innovativeness and entrepreneurship (Zahao, 2005; Mirjana et al., 2018; Ji and Bai, 2018).

However, market regulations in the country should increase entrepreneurship to provide innovation activities to result in entrepreneurship (Jackson et al., 2014; Babina and Howell, 2018; Ozarali and Rivenburgh, 2016; Yurtkoru et al., 2014; Nystrom, 2010; Belas et al., 2017).

The reason why Golden and Lee's (2003) study could not find a relationship between national innovation systems and entrepreneurial activities may be that it was carried out in developed countries (the Netherlands, Ireland and Finland). Yavas and Yalnizer's (2012) research that was found to be a negative correlation between the Human Development Index and early-stage entrepreneurial activity rates had a finding similar to this research finding. In other words, the entrepreneurial activities in the country decrease due to the satisfaction of the market as the development level of the countries increases.

\section{Concepts in the Research}

This section of the research includes explanations about innovation and innovation ability, entrepreneurial intention and business dynamism in the research model created for the purpose of the research.

\subsection{Concepts of Innovation and Innovation Ability}

As a result of the disappearance of borders between countries with globalization, the need for new goods and services is increasing day by day in order to meet the rapidly changing demands and needs of consumers. Thanks to the developments in information and communication technologies, consumers are informed about the products/services in a short time and make efforts to reach these products. This constantly prompts companies to seek innovation. When the literature is examined, there are different debates between the concepts of innovation and novelty, but innovation is included as novelty in this study.

Innovation can be defined as a new or improved product, process, or a combination of both, which is tailored to potential users (product) or made available by the unit (process) and is significantly different from the unit's previous products and processes (Oslo Manuel: 2018: 20).

Innovation is the process of turning the best ideas into reality, which triggers a creative idea that creates a series of innovative events. Innovation is the creation of new value. Innovation is a process that turns new ideas into new value turning an idea into value (Okpara, 2007).

The concept of innovation is defined as a new structure or management process, a policy, a new plan or program, a new production process, a new product or service produced in the business (Kalay et al., 2015).

Innovations emerge as a result of different factors. According to Peter F. Drucker, these factors take place in two classes as those arising from the company or the sector (unexpected developments, nonconformities, process needs, changes in the sector and market structure) and those arising from the intellectual environment outside the company (changes in demographic structure, perception changes, new information) (ChannelMarangoz, 2012:49).

Changes in factors affecting innovation due to environmental changes also led to changes in innovation classifications. Compared to the previous edition, the 2018 edition of the Oslo Manuel, which was prepared by OECD as a guide for the collection and interpretation of data on innovation, reduced the four types of innovation (product, process, organization, marketing) to two types; product innovations and business process innovations (Oslo Manuel, 2018: 20).

Thus, the concept of innovation which is different in its definitions and classifications has become a global concept that concerns country governments, companies, NGOs and consumers.

In recent years, the competition between countries has shifted especially to the fields of science, industry and technology, thereby making research and development studies of the national economies, effective use of information and communication technologies and technological infrastructure more important. Developed countries allocate more money from their budgets for $R \& D$ and innovation activities in order to increase product quality and standards and to decrease product costs (Dam and Yildiz 2016).

For example, the European Union (EU) defines innovation as a key factor in the competitiveness of the industry sector. This is because the industry sector accounts for $80 \%$ of Europe's exports. In addition, $80 \%$ of R\&D investments in private sector come from manufacturing. Therefore, the industrial modernization of the EU should be comprehensive and cover the successful commercialization of product and service innovations, the industrial use of innovative manufacturing technologies and innovative business models (https://ec.europa.eu/growth/industry/innovation_en, 
Accessed on: August 15, 2019). As can be seen from the example, the EU has identified innovation activities as the way to ensure the competitiveness of the industrial sector, which has the most important share in its exports.

However, it is not sufficient for country governments to set only innovation as a target. There is a need for qualified and entrepreneurial manpower, an environment that enables the production and dissemination of new ideas, mechanisms that support innovation and access to capital in order to establish an innovation economy in a country or region. The state plays a facilitating and catalyst role here; invests in human resources, research, technology development and innovation, and promotes such investments (Yorgancilar, 2011).

A systematic work can result in increasing innovation capacities of countries. Thus, innovative systems have been established in countries under the name of innovation systems. Innovation systems are systems of close collaboration between private and public enterprises, universities, private and public research institutes and government bodies aimed at developing innovation in line with the needs of consumers for new or developing products or services (Hancioglu and Atay, 2018).

Innovation systems can be company, industry, regional, national and international. The purpose of the innovation systems is to give the related part the ability to innovate. Innovative ability is defined as the capacity to provide access to the development and implementation of innovative technologies for design and production (Mohammad et al., 2019).

Governments have an important role in increasing innovation abilities in the countries. However, no consensus has been reached in the literature regarding the criteria according to which innovation abilities in countries will be evaluated. However, 10 components of innovation ecosystem, one of the 4 sub-indices (environment provisioning, human capital, markets and innovation ecosystem) of the Global Competitiveness Index announced by the World Economic Forum, which is also included in the data analyzed in this research, gain importance in terms of showing the innovation ability of countries. The components of the innovation ecosystem in the Global Competitiveness Index are workforce diversity, cluster development status, international joint inventions, multi-stakeholder collaboration, scientific publications, patent applications, $R \& D$ expenditures, quality of research institutes, customer complexity and trademark practices (GCI, 2018: 633).

When innovation ability is evaluated in terms of companies, they can rapidly innovate if they provide the necessary resources, a strong motivation for innovation and an organizational climate that will encourage innovation ideas. Innovation ability in businesses can be defined as the ability to constantly transform knowledge and ideas into new products, processes and systems for the benefit of both the organization and stakeholders (Popa et al., 2010). Innovation may help companies play a dominant role in shaping the future of their industry. High-performance innovative companies can maintain their strong creative abilities and consistently bring high-quality products to the market faster, more often and at a lower cost than their competitors. Moreover, these companies use their processes and system innovation as a way to further improve their products and add value to customers. This combination forms a dynamic and sustainable strategic position, making the organization a target that constantly moves against competitors (Lawson and Samson, 2001).

\subsection{Concepts of Entrepreneurial Intention and Business Dynamism}

There are different definitions for the concept of entrepreneurial intention, which is considered as important in terms of the initiation of entrepreneurial activities that are accepted as a force that activates natural and human resources in the social and economic development of countries.

Entrepreneurial intention is to think about starting a new business and is that the person believes this work will be done on a planned basis at one point in the future (Thompson, 2009).

According to Karabulut (2016), entrepreneurial intention is defined as a person's intention to choose entrepreneur for her/his career, but Celik et al. (2014) think that it reflects the idea of starting a business and launching an incentive that will enable the person to evaluate potential opportunities in the environment rather than other career options.

Entrepreneurial intention is considered the key to understanding the entrepreneurial process and can be accepted as the first step in a long and complex entrepreneurial process. If entrepreneurial intention is the single strongest determinant of entrepreneurial behavior, it is particularly significant to investigate its premises and determinants for understanding the entrepreneurial process (Mirande et al., 2017). Determining the factors that affect entrepreneurial intention is considered important in terms of displaying entrepreneurial behaviors through the creation of entrepreneurial intention. 
Those with entrepreneurial intentions do not actually need to set up a new business, because numerous personal conditions and environmental factors can counteract it. Some people with entrepreneurial intentions can proceed to do formally advanced actions to become a startup, i.e. to establish a new company (Thomson, 2009).

According to Shamsudin et al. (2018), entrepreneurial intention are influenced by the factors such as tendency to act, perceived behavioral control, family history, culture/religious belonging, university community, self-efficacy, government policies, personal characteristics, attitude, subjective norms and entrepreneurship training.

Paco et al.'s (2017) study examined the factors affecting entrepreneurial intention under three sections as perception of a person's behaviors, perceived social norms and self-efficacy.

Entrepreneurial intentions are not only influenced by the personal factors mentioned above. According to Karabulut (2016), entrepreneurial intentions also depend on external factors such as environment, market, finance and regulations.

Innovation abilities in countries may also be among the main factors affecting entrepreneurial intentions. Entrepreneurs play an important role both in creating the components that form innovation abilities and in evaluating the opportunities that may arise after these components are created. According to Drucker (1985: 20), innovation is a special tool for entrepreneurs. Entrepreneurs benefit from change as an opportunity for a job or a different service. Entrepreneurs need to carry out a conscious search for innovation sources, changes that show successful innovation opportunities and their effects.

Innovation ability is not considered as the only factor affecting entrepreneurial intention. Among the environmental factors that affect entrepreneurial intention, another factor consisting of different components is the elements of business dynamism. It is important for entrepreneurial studies to know the role of the elements of business dynamism in the impact of innovation ability on entrepreneurial intentions in the countries.

According to the World Economic Forum's Global Competitiveness Index, which measures the business dynamism in the countries, business dynamism is defined as the capacity of the private sector to produce and adopt new technologies and new ways of arranging business through a culture of change, risk, new business models and administrative rules that allow companies to enter into and exit the market easily. Furthermore, business dynamism is considered as an element of the innovation ecosystem (GCR, 2018: 42).

As a result, entrepreneurial intention is affected by personal factors, but environmental factors have an important role in the formation of these personal factors. Innovations that are included in these environmental factors and is considered an integral part of entrepreneurship may influence entrepreneurial intentions thanks to the innovation ability in the countries. However, business dynamism, which is one of the other environmental conditions affecting entrepreneurial intention other than innovation ability in countries, should also be supported to become this impact more positive.

\section{Research Method}

Within the framework of the main purpose of determining the mediator role of business dynamism in the impact of innovation ability of countries on entrepreneurial intentions, the variables were firstly identified and the conceptual model created is presented in Figure 1. The data were compiled and the relationships between the variables in the data set were determined to test the conceptual model of the research. Then, the hypotheses were developed within the framework of the conceptual model of the research, and they were tested by mediation analysis using PROCESS, a versatile modeling tool, with the data set obtained.

\subsection{Research Model, Data and Method}

The data of innovation ability and business dynamism of 45 countries obtained from the World Economic Forum's Global Competitiveness Index for 2018 and their data of entrepreneurial intention obtained from the Global Entrepreneurship Monitor (GEM) were included in the research.

The innovation ability of the countries was determined as independent variable, business dynamism as mediator variable and entrepreneurial intentions as dependent variable in the model for the purpose of the study. Innovation ability, which is an independent variable, consists of the components of the innovation ecosystem in the Global Competitiveness Index and includes workforce diversity, cluster development status, international joint inventions, multi-stakeholder collaboration, scientific publications, patent applications, R\&D expenditures, quality of research institutes, customer complexity and trademark practices. According to the World Economic Forum's Global Competitiveness Index, business dynamism as mediator variable is defined as the capacity of the private sector to produce and adopt new technologies and new ways of arranging business through a culture of change, risk, new business models and administrative rules that allow companies to enter into and exit the market easily. Entrepreneurial 
intention as dependent variable are defined by GEM as a percentage of the population between the ages of 18-64, who are characterized as secret entrepreneurs, except for individuals who are involved in any stage of entrepreneurial activities and who want to start a business within three years.

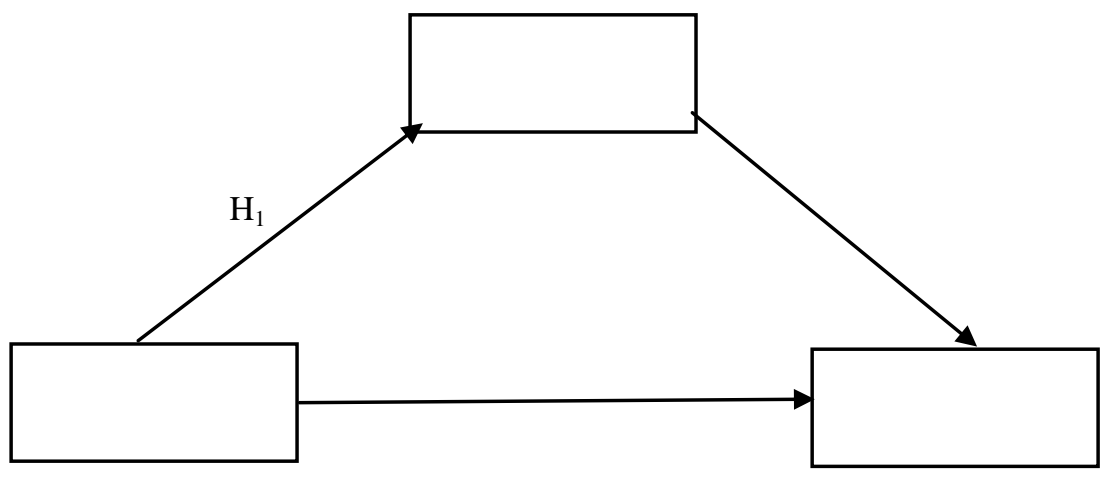

Figure 1. Conceptual Model

The hypotheses of the research were determined within the framework of the conceptual model created for the main purpose of the research.

$\mathrm{H}_{1}$ : The innovation ability rates of countries have a significant impact on business dynamism rates.

$\mathrm{H}_{2}$ : The business dynamism rates of countries have a significant impact on entrepreneurial intention rates.

$\mathrm{H}_{3}$ : The innovation ability rates of countries have a significant impact on entrepreneurial intention rates.

$\mathrm{H}_{4}$ : Business dynamism rates have a mediator role in the impact of the innovation ability rates of countries on entrepreneurial intentions.

The conceptual model and hypotheses of the research were formed as a mediator model. The purpose of the mediation analysis is to determine to what extent the $\mathrm{X}$ variables, which are assumed to have causal effects on the dependent variable $\mathrm{Y}$, affect the dependent variable $\mathrm{Y}$ through one or more mediating variables (M) (Hayes, 2012). The reason why mediation analysis is often used by researchers to evaluate indirect effects is to describe the relationships between variables as well as to provide a more functional understanding (Preacher and Hayes, 2004) and to focus on how the causal effect works (Hayes and Rockwood, 2017).

Mediation analysis, which is frequently preferred especially in psychological research, is generally guided by the procedures proposed by Baron and Kenny (1986). The procedure proposed by Baron and Kenny (1986) was determined as three-stage (Figure 2)

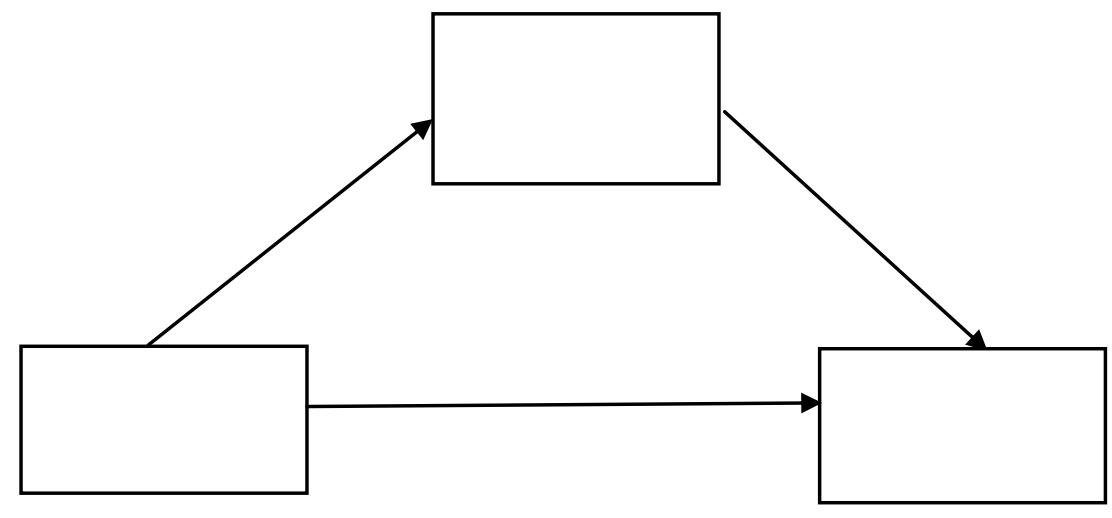

Figure 2. Mediator Effect

- At the first stage, the total effect of the independent variable $\mathrm{X}$ on the dependent variable $\mathrm{Y}$ is determined $(\mathrm{X} \rightarrow \mathrm{Y})$.

- At the second stage, the independent variable $X$ should be associated with the mediator variable M. Otherwise, the mediator effect is not possible if the independent variable is not associated with the mediator $(X \longrightarrow M)$. 
- When $\mathrm{X}$ is statistically controlled at the third stage after the second criterion is met, the mediator variable $\mathrm{M}$ should have a statistically significant relationship with the dependent variable Y.

When the conditions of these three stages are met and the mediator variable $\mathrm{M}$ remains constant, $\mathrm{M}$ can be considered a mediator in the impact of $\mathrm{X}$ on $\mathrm{Y}$ if the direct effect of $\mathrm{X}$ on $\mathrm{Y}$ is smaller than the effect of $\mathrm{X}$ on $\mathrm{Y}$ that is measured without controlling $\mathrm{M}$, i.e. approaching zero.

Preacher and Hayes (2004) have stated that mediation analysis is frequently used in psychological research in their studies, but the significance tests of indirect effects are rarely performed and are based on two possibilities, although these cannot be fully explained. The first one of these possibilities is that the statistical significance of the difference between the total effect of $\mathrm{X}$ on $\mathrm{Y}$ and the direct effect of $\mathrm{X}$ on $\mathrm{Y}$ is not shown as a condition for mediation by Baron and Kenny. The second one is that some of the most commonly used programs for regression (such as SPSS and SAS) are to test the null hypothesis that the indirect effect is equal to zero, while performing all the necessary tests to mediate according to Baron and Kenny's criteria. Baron and Kenny (1986) described a procedure developed by Sobel (1982), which would later be referred to as the Sobel test, allowing a more direct test of an indirect effect. Although commonly used programs provide all the information required for the researcher to run the Sobel test manually, some extra hand calculations are required.

The normal theory approach, which was developed by Sobel (1982) with the alternative ways and use of structural equation modeling (SEM) in the analysis of the mediator effect, was incorporated into popular SEM software applications such as LISREL (Joreskog and Sorbom, 1996) and EQS (Bentler, 1997). The current version of AMOS applies a boot approach to evaluate indirect effects (Arbuckle and Wothke, 1999).

Based on these explanations, the conceptual model of the research was evaluated with PROCESS, a multifaceted modeling tool developed by Andrew F. Hayes (2012), which integrates many functions for SPSS and SAS for different statistical analyses such as mediator, regulatory and conditional process models, by mediation analysis.

\subsection{Analysis and Findings}

For the research, the multivariate normality hypothesis for variables included in the data set was first evaluated by Mardia's skewness and kurtosis coefficient and the kurtosis value was calculated as 1.915 and the critical ratio (c.r.) was calculated as $0.927<1.96$. Following providing the multivariate normality hypothesis, the variance inflation factors (VIF) were examined in order to test whether there was a multicollinearity and the VIF values of the variables were found to be between 1 and 10. Then, Pearson's correlation coefficient was performed to determine the direction and degree of the relationships between the variables. The arithmetic mean, standard deviation, correlation coefficients and VIF values related to the variables are given in Table 1 as a result of the analysis on the research variables and their dimensions in the study.

According to Pearson's correlation analysis results, it is seen that there are negative and moderately significant relationships between entrepreneurial intentions and innovation ability $(r=-0.535, p<0.01)$ and business dynamism $(r=-$ $0.587, \mathrm{p}<0.01)$. There is also a strong and significant relationship in the same direction between innovation ability and business dynamism $(\mathrm{r}=0.842, \mathrm{p}<0.01)$. According to the results of the correlation analysis, the business dynamism will increase but the entrepreneurial intentions will decrease as the innovation abilities of the countries increase. Similarly, the development of business dynamism positively affects the innovation ability of countries, while it negatively affects entrepreneurial intention.

Table 1. Average, St. Deviation, Correlation and VIF Values

\begin{tabular}{|l|l|l|l|l|l|l|l|}
\hline & Variable & Avg. & Sd. & $\mathbf{1}$ & $\mathbf{2}$ & $\mathbf{3}$ & VIF \\
\hline $\mathbf{1}$ & $\begin{array}{l}\text { Entrepreneurial } \\
\text { Intention }\end{array}$ & 22.78 & 16.44 & $\mathbf{1}$ & & & - \\
\hline $\mathbf{2}$ & $\begin{array}{l}\text { Innovation } \\
\text { Ability }\end{array}$ & 54.70 & 18.38 & $-0.535^{* *}$ & $\mathbf{1}$ & & 3.429 \\
\hline $\mathbf{3}$ & $\begin{array}{l}\text { Business } \\
\text { Dynamism }\end{array}$ & 64.68 & 10.47 & $-0.587^{* *}$ & $0.842^{* *}$ & $\mathbf{1}$ & 3.429 \\
\hline
\end{tabular}

$\mathrm{p}<0.01$,

The mediator effect of business dynamism on the impact of innovation ability of countries on entrepreneurial intentions was evaluated and the results in Table 2 were obtained. According to the analysis results of the research, it was concluded that business dynamism had a mediator effect on the impact of innovation abilities of countries on entrepreneurial intentions. 
At the first stage of the regression analysis for the model created in line with the purpose and theory of the research, only the independent variable was included in the analysis and the innovation ability was found to have a significant impact on entrepreneurial intentions $(\beta=-0.5350 ; \mathrm{t}=-4.15 ; \mathrm{p}<0.05)$. The relationship, which was analyzed during the second stage, was between the independent variable and the mediator variable. The impact of innovation ability on business dynamism $(\beta=0.8417 ; \mathrm{t}=10.22 ; \mathrm{p}<0.05)$ was found to be significant.

At the third stage, there are relationships arising from the incorporation of both the independent variable and the mediator variable into the model. At the last stage, the $\mathrm{p}$ significance value indicating the impact of the independent variable on the dependent variable is greater than or very close to 0.05 , the critical value, which is an indicator of the significance of the mediator effect of the model. For the research model, the $p$ significance value of the impact of innovation ability, independent variable, on entrepreneurial intentions $(\beta=-0.1399 ; \mathrm{t}=-0.61 ; \mathrm{p}>0.05)$ was seen to be greater than 0.05 . Then, the mediator role of business dynamism can be mentioned. Therefore, the impact of business dynamism, mediator variable, on entrepreneurial intentions $(\beta=-0.4694 ; \mathrm{t}=-2.04 ; \mathrm{p}<0.05)$ is understood to be significant.

Table 2. Mediation Regression Analysis Results

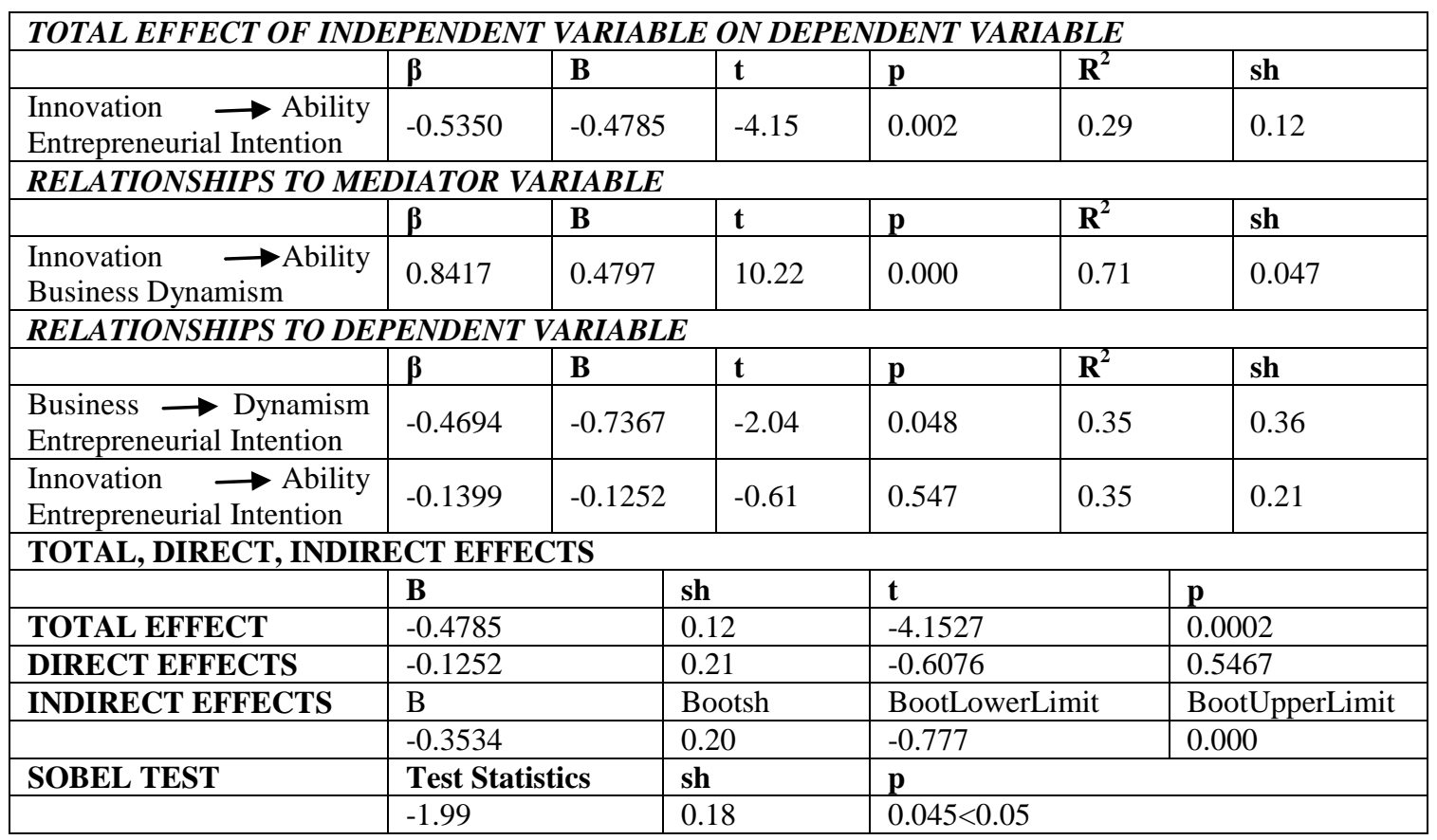

The most important feature that distinguishes the mediation modeling and macro modeling developed by Hayes (2009, 2012) from other mediation analyses is to explain the mediator effect by calculating a confidence interval with bootstrapping rather than explaining it only with a p significance value. Therefore, it will be appropriate to evaluate the direct, indirect and total effects in Table 2 . The total effect in the model is only the causality relationship between the independent variable and the dependent variable. There are the direct effect $(B=-0.1252, \mathrm{p}>0.05)$ and indirect effect $(B=-0.3534)$ of the independent variable on the dependent variable, when the mediator variable is included in the model with the total effect $(B=-0.4785, p<0.05)$ in the research model. Considering the $B$ regression coefficients, it can be stated that the values of direct and indirect effects are equal to the total effect and there is a mediator effect. However, the significance of this mediator effect should be decided by examining the confidence interval valuescalculated with bootstrapping. If there is no zero value between the lower limit and upper limit $(-0.777$ and 0.000$)$ of the confidence interval calculated for the research model, it states that the model is significant. It is possible to confirm this result with a stronger test. According to the Sobel test result, the mediator effect $(\mathrm{z}=-1.99, \mathrm{p}=0.045<0.05)$ is understood to be significant.

It was determined that all of the hypotheses of the research, which was tested by regression analysis with the implementation of the mediation effect analysis proposed by Hayes $(2009,2012)$, were confirmed and business dynamism had a mediator effect in the impact of innovation abilities of countries on entrepreneurial intentions.

\section{Conclusion}


Countries are addressed in three categories according to the Global Competitiveness Report in examining entrepreneurship profiles. These categories are determined as production-driven economies, efficiency-driven economies and innovation-driven economies. This classification is based on the gross domestic product (GDP) level per capita.

As a result of the maturation of the economy in innovation-oriented countries, the increasing level of welfare affects and develops both the production and service sectors. Thus, the diversity and developments required by the economy contribute to the formation of entrepreneurial activities open to innovation and opportunities. While industrialization is supported in the pursuit of higher productivity and scale economies in efficiency-driven economies, a business dynamism develops towards gaining importance to the service sector rather than production (Lakovlena, 2011; Karadeniz, 2014).

The results of the research model designed as a mediation model and the results obtained with the correlation analyses were shaped within the framework of these explanations. When the results of the relationships between the variables are evaluated, it is noteworthy that there are reverse relationships of business dynamism with both innovation ability and entrepreneurial intentions. However, it is known that innovation-driven economies enable the development of entrepreneurial activities open to innovation and opportunities. The result of the research conflicts with it.

Similarly, the mediation model tested with regression analysis concluded that business dynamism had a mediator role in the causality relationship between innovation ability and entrepreneurial intention, but there was a negative causality relationship.

Although the reverse relationships of innovation ability and business dynamism with entrepreneurial intentions in both correlation and regression analysis results are not in line with the explanations in the literature, it has been stated in the 2019 report of the Global Entrepreneurship Monitor (GEM) that these relationships have recently had an adverse effect. According to the 2019 report of GEM, entrepreneurship is seen as a tool to earn income, as there is less employment opportunities in low income economies. The entrepreneurial activities of individuals are perceived as an obligation brought by the national economy and this level of obligation decreases with the increase of employment opportunities as the level of economic development increases.

Lakovlena et al. (2011) have stated that developing countries have efficiency-driven economies, while developed countries have innovation-driven economies. Since the economies of developing countries are less stable than those of developed countries, it creates a difficult environment to do a career and find a job, but the demand for salaried work is higher in developed countries. Besides, unstable economies offer more opportunities for entrepreneurial activities than stable economies.

Then, increased welfare level and sufficient employment opportunities in developed economies whose innovation ability is increasing cause the country's population not to see entrepreneurship as a career option, and they prefer to earn income as a salaried employee rather than an entrepreneur. In other words, they do not show entrepreneurial intentions as they do not feel obliged to earn income. Another remarkable factor in the 2019 report of GEM is that very few people want to start a new business in developed economies in Europe and North America, where the level of welfare has reached a certain level, and the rest of the population does not intend to do so in the future. This is a reality that supports the research result for entrepreneurial intentions and activities.

After all, the business dynamism in the countries becomes more active as a result of the diversification and development of the industrial sector in the countries when the innovation ability increases. As a result of innovation ability and business dynamism, new employment opportunities will also emerge when opportunity-based entrepreneurial activities increase. Therefore, individuals will prefer to be a salaried employee and will not develop entrepreneurial intention in the economy with certain saturation. Although the transition of countries from an efficiency-oriented economy to an innovation-oriented economy, i.e. the increase in innovation ability, creates opportunities for entrepreneurial activities in the first place, it turns into a negative effect with the maturation of the economies.

The research was limited to countries whose data could be accessed using secondary data. More detailed results can be obtained with the country comparisons of the research and the expansion of different variables with different models including especially economic indicators of countries.

\section{References}

Arbuckle, J.,andWothke, W. (1999). AMOS 4 user'sreferenceguide, Chicago: Smallwaters Corporation.

Babina, T. Ve Howell S.T. (2018). EntrepreneurialSpilloversfromCorporate R\&D.NBER WorkingPaper No. w25360 
Baron, R.M. andKenny, D.A. (1986). TheModerator-Mediator Variable Distinction in Social Psychological Research: Conceptual, Strategic, and Statistical Considerations. Journal of Personality and Social Psychology, 51(6), 1173-1182.

Belas, J.,Gavurova, B., Schonfeld, J., Zvarikova, K., Kacerauskas, T. (2017).

Social and Economic Factors Affecting the Entrepreneurial Intention of University Students.Transformations in Business \&Economics, 16-3(42), 220-239.

Bentler, P. M. (1992). On the fit of models to covariances and methodology to the Bulletin .PsychologicalBulletin, 112(3), 400-404.

Çelik, A., İnce, M., Bozyiğit, S. (2014). Üniversite Öğrencilerinin Girişimcilik Niyetlerini Etkileyen Ailesel Faktörleri Belirlemeye Yönelik Bir Çalışma.ÖmerHalisdemir Üniversitesi İktisadi ve İdari Bilimler Fakültesi Dergisi, 7(3), 113-124.

Dam, M.M. and Yıldız, B. (2016). BRICS-TM Ülkelerinde AR-GE ve İnovasyonun Ekonomik Büyüme Üzerine Etkisi: Ekonometrik Bir Analiz.Akdeniz İ.I.B.F. Dergisi, (33), 220-236.

Drucker, P. F.(1985). Innovation and Entrepreneurship. Harper \& Row Publishers Inc, New York. S. 20

GEM (2019), 2018/2019 Global Report. Global EntrepreneurshipMonitor

Golden, W.;Higgins, E.; Lee, S.H. (2003). National Innovation Systems and Entrepreneurship, Centre for Innovation Stctural Change. CISC WorkingPaper, No: 8

Hancioğlu, Y. and Atay, Ö. (2018). Dünya İnovasyon Lideri İsviçre Ve Türkiye Ulusal İnovasyon Sistemlerinin Karşılaştırmalı Bir Değerlendirmesi. Işsletme Fakültesi Dergisi, 19 (1), 51-88

Hayes, A.F. (2009). Beyond Baron and Kenny: Statistical Mediation Analysis in the New Millennium.Communication Monographs, 76(4), 408-420.

Hayes, A.F. (2012). PROCESS: A Versatile Computational Tool for Observed Variable Mediation, Moderation, and Conditional Process Modeling, [White Paper]. http://www.afhayes.com

Hayes, A. F. and Rockwood, N. J. (2017). Regression-based statistical mediation, moderation, andconditional process analysis: Observations, recommendations, andimplementation. Behaviour Research and Therapy, 98, 39-57.

Jackson, F.H., Sara, Tejinder, Kahai, Simran K. (2014). Determinants Of Innovative Capability Of A Country AndIts Role In Economic Growth.International Business \& Economics Research Journal, 13(5), 1141-1148.

Ji, Y. andBai, Y. (2018). Innovation Capacity and Entrepreneurial Intention: The Moderating Effects of Entrepreneurial Atmosphere.Journal of Applied Business and Economics, 20(1), 68-84.

Jöreskog, K.G. andSörbom, D. (1996). LISREL 8 User's reference guide. Chicago: Scientific Software.

Kalay, F, Tuncer, C. O., Kızıldere, C., Kalay, H.A. (2015). Stratejik İnovasyon Uygulamalarının Firma İnovasyon Performans1 Üzerindeki Etkileri.Bilgi Ekonomisi ve Yönetimi Dergisi, Cilt: X (II), 67-77.

Karabulut, A. T. (2016). PersonalityTraits on Entrepreneurial Intention. Procedia - Social and Behavioral Sciences, $229,12-21$

Karadeniz, E. (2014). Türkiye'de Ve Bölgelerde Girişimcilik. KOSGEB, TEB, Yeditepe Üniversitesi Yayını.

Lakovleva, T.,Kolvereid, L. and Stephan, U. (2011). Entrepreneurial intentions in developing and developed countries. Education + Training, 53(5), 353-370.

Lawson, B. andSamson, D. (2001). Developing Innovatıon Capability In Organisations: A Dynamic Capabilities Approach. InternationalJournal of Innovation Management, 5(3), 377-400.

Marangoz, M. (2012). Girişimcilik, Beta Basım Yayım Dağıtım A.Ş., İstanbul. s.49

Miranda, F.J., Mera, A.C., Rubio, S. (2017). Academic entrepreneurship in Spanish universities: An analysis of the determinants of entrepreneurial intention. European Research on Management and Business Economics, 23(2017), 113-122.

Mirjana, P. B. Ana, A.,Marjana, M.S. (2018). Examining determinants of entrepreneurial intentions in Slovenia: applying the theory of planned behaviour and an innovative cognitive style .EconomicResearch-Ekonomska Istraživanja, 31(1), 1453-1471.

Mohammad, I.N., Massie, J.D.D., Tumewu, F.J. (2019). The Effect Of Entrepreneurial Orientation And Innovation Capability Towards Firm Performance In Small And Medium Enterprises. Journal EMBA. 7 (1), 1-10.

Nyström, K. (2010). Business regulation and red tape in the entrepreneurial economy.Centre of Excellence for Science and Innovation Studies, Electronic Working Paper Series, Paper No: 225.

Okpara, F.O. (2007). The Value Of Creatıvity And Innovation In Entrepreneurship. Journal of Asia Entrepreneurship and Sustainability, III (2), 1-14.

Oslo Manual 2018, Guidelines for Collecting, Reporting and Using Data on Innovation, 4th Edition s. 20

Ozaralli, N. andRivenburgh, N.K. (2016). Entrepreneurial intention: antecedents to entrepreneurial behavior in the U.S.A. and Turkey. Journal of Global Entrepreneurship Research, 6:3 
Popa, L.L.,Preda, G., Boldea, M. (2010). A Theoretıcal Approach Of The Concept Of Innovation. Managerial Challenges of the Contemporary Society, Issue 1, 151-156.

Preacher, K.J. and Hayes, A.F. (2004), SPSS and SAS procedures for estimating indirect effects in simple mediation models.Behavior Research Methods, Instruments, \& Computers, 36 (4), 717-731.

Shamsudin, A. S.,Adelaja, A. A., Minai, M. S. (2018). Conceptualizing The Effect Of Entrepreneurial Education And Industrial Interface Mix In Enhancing The Entrepreneurial. Journal of EntrepreneurshipEducation, ResearchArticle, $\mathrm{Vol}: 21$.

Sobel, M. E. (1982).Aysmptotic confidence intervals for indirect effects in structural equation Models. In S. Leinhardt (Ed.), Sociological methodology, San Francisco:Jossey-Bass, 290-212.

Thompson, E. R. (2009). Individual Entrepreneurial Intent: Construct Clarification and Development of an Internationally Reliable Metric. Entrepreneurship Theory and Practice, 33 (3), 669-694.

World Economic Forum, The Global Competitiveness Report 2018, s. 633

Yavaş, Ö. andYalnızer, Ö. (2012). Girişimcilik Potansiyelinin Belirlenmesinde İnsani Gelişme Endeksi’nin Önemi: Türk Dünyası Ülkeleri ile Seçilmiş Ülke Gruplarının Karşılaştııılması.10. Uluslararası Türk Dünyası Sosyal Bilimler Kongresi, Akmescit-Kırım-Ukrayna.

Yorgancılar, F. N. (2011). Sürdürülebilir Rekabet Anlayışı Olarak Yenilik Yeteneği.Sosyal Ekonomik Araştırmalar Dergisi, 11 (21), 379-426.

Yurtkoru, E.S., Kabadayı Kuşçu, Z., Doğanay, A. (2014). Exploring the antecedents of entrepreneurial intention on Turkish university students.Procedia - SocialandBehavioralSciences, 150, 841-850

Zhao, F. (2005). Exploring the synergy between entrepreneurship and innovation. International Journal of Entrepreneurial Behaviour \& Research, Vol. 11(1), 25-41.

https://ec.europa.eu/growth/industry/innovation_en, Erişim Tarihi: 15.08.2019 